al-Ihkam: Jurnal Hukum dan Pranata Sosial, 14 (1), 2019: 99-123

ISSN: 1907-591X, E-ISSN: 2442-3084

DOI: http://doi.org/10.19105/al-ihkam.v14i1.2290

\title{
Specific Treatment of Elderly Pilgrims on Hajj According to Hadith; The Approach of Mukhtalif Ahadis
}

\author{
Masyithah Mardhatillah \\ Institut Agama Islam Negeri Madura, Jl. PangIegur KM. 4, Pamekasan-69317 \\ Email:masyithah.mirza@gmail.com
}

Article history: Received: 13 Mei 2019, Accepted: 27 Juni 2019, Published: 11 Juli 2019

\begin{abstract}
:
Most of Indonesian hajj pilgrims are elderly due to approximately 23 years waiting period. This paper aims to elaborate specific treatment of elderly pilgrims according to the hadith. Some hadith imply indirect prohibition to perform hajj by themselves while others still motivate the hajj in a hard condition. Using the approach of mukhtalif ahâdits, this paper seeks to answer three questions. First, how did hadith say about specific treatment of elderly hajj pilgrims. Second, how to deal with two groups of hadith which slightly look different. Third, how is proper contextual interpretation on the hadith in Indonesian contemporary life. The data compilation is through literature reviews and interviews. Then, the two groups of hadith are compromised using a method called al-jam'u wa altawfiq. It truns out that the first hadith applies for those who can't really perform the hajj while another is for those with physical problems but could still stand for hajj using some facilities and policies. Those all lead to an inevitable need for a special hajj manasik for elderly so they could perform the hajj with better preparation.
\end{abstract}

Keywords:

Elderly Hajj Pilgrims; Hadith; Mukhtalif Ahâdits; Manasik

Author correspondence email: masyithah.mirza@gmail.com Available online at: http://ejournal.iainmadura.ac.id/index.php/alihkam/ Copyright (c) 2019 by al-ihkam. All Right Reserved 


\begin{abstract}
Abstrak:
Dengan waktu tunggu keberangkatan kurang lebih 23 tahun, sebagian besar jama'ah haji Indonesia adalah lansia. Penelitian ini mendiskusikan pandangan hadist soal perlakuan khusus terhadap jama'ah lansia. Beberapa hadist menyiratkan imbauan untuk tidak melaksanakan haji secara langsung, sedang beberapa lain tetap memotivasi pelaksanaan haji dalam keadaan sulit sekalipun. Dengan pendekatan mukhtalif ahâdits, penelitian ini fokus menjawab tiga persoalan. Pertama, bagaimana pandangan hadist terhadap jamaah lansia. Kedua, bagaimana mengompromikan dua (kelompok) hadist yang sekilas tampak berbeda. Ketiga, bagaimana interpretasi kontekstual hadisthadist tersebut dalam konteks Indonesia dewasa ini. Data penelitian didapat melalui penelusuran pustaka dan wawancara. Dua kelompok hadist kemudian dikompromikan dengan metode al-jam'u wa al-tawfiq. Hasilnya menunjukkan bahwa hadist pertama berlaku bagi jama'ah yang benar-benar tidak bisa melaksanakan haji, sedang yang kedua adalah bagi mereka dengan kemampuan fisik yang minim namun masih memanfaatkan fasilitas dan kebijakan yang ada. Dari situ, adanya sebuah manasik (kelas haji) khusus lansia di Indonesia menjadi keniscayaan agar jama'ah lansia dapat semakin maksimal memersiapkan dan melaksanakan haji.
\end{abstract}

Kata Kunci:

Haji Lansia; Hadist; Mukhtalif Ahâdits; Manasik

\title{
Introduction
}

As the last pillar of Islam, performing hajj is the most challenging one as it needs various 'abilities' ranging from financial, physical and social aspect even knowledge mastery. In Indonesia, the challenge is also about the quota and the long waiting period which can take place, at maximum, 30 years right after the registration. ${ }^{1}$ This makes very much sense to happen in the world's largest Moslem country. Together with other relating factors, those play a big role in segmenting the hajj pilgrims. Most of them, about $60 \%$ at 2018, come

1The most recent waiting period is 23 years counting from the registration date. Interview with Mr. Afandi, Former Chair of Hajj Division, Pamekasan Branch of Ministry of Religious Affair, at his office, Jl. Brawijaya, Pamekasan, August 27, 2018. 
from elderly who typically suffer various types of health problem. ${ }^{2}$

In fact, the situation of hajj requires every pilgrim to maintain good health as it would determine on how they perform the series of worship. Meanwhile, the huge people from all over the world coming to the single place for the same purpose make the crowd unbearable. The heat climate of Mecca and its surrounding makes the condition even more challenging so not every pilgrim may do the same as they have different health condition. ${ }^{3}$ Therefore, specifically to the elderly or those who have serious physical problems, some facilities and system are well prepared to help them performing the hajj well.

Considering the healthy and physical problem, at very least, elderly have two main choices in performing the hajj, either by performing by themselves along with their physical limitation or by appointing someone else to do on behalf of him/her. So far, there is no rigid rule about this very specific thing and it refers to personal preference. Therefore, it is important to know how religious source, particularly hadith, speaks about this matter which is also a constant problem arising in every hajj session year by year. Hadith, in this extent, is the considerable source to note as it elaborates general thing into specifics and explore the living story of Prophet Muhammad lively. Moreover, previous researches on elderly pilgrims were more

2Redaksi, "60 Jama'ah Haji Indonesia 2018 Didominasi Lansia”, in "https://haji.okezone.com/read/2018/04/25/398/1891271/60-jamaah-hajiindonesia-2018-didominasi-lansia. (Accessed on August 01, 2018). A study found that the majority $(79 \%)$ of hospitalized patients during the 1423 Hijriyah hajj session were up to 40 years and more than $1 / 3$ of them were up to 60 years. See Tariq A. Madani (et al), "Causes of Hospitalization of Pilgrims during the Hajj Period of the Islamic Year 1423 (2003)," Ann Saudi Med, Vol. 26, No. 5, (September-October 2006), 349. Another study mentioned penumonia as the major cause of serious illness during the session of hajj. See Yaseer Mandourah (et al), "Clinical and Temporal Patterns of Severe Pneumonia Causing Critical Illness during Hajj", BMC Infectious Disease Vol. 12 (117), (2012), 7. In addition to those two, there also found the respiratory tract infections as the common illness of hajj pilgrims. See Abdulaziz H. Alzeer, "Respiratory Tract Infection during Hajj", Annals of Thoracic Medicine, Vol. 4, No. 2 (Apr-Jun 2009), 50.

3There found some factors beyond the extreme circumstances of hajj session. They are physical exhaustion, exposure to foreign strains of organism and overcrowding (around 2 million pilgrims in the restricted area). A. Alzeer, "Tuberculosis is the Commonest Cause of Pneumonia Requiring Hospitalization During Hajj (Pilgrim to Makkh)," in Journal of Infection, Vol. 36, No. 3 (1998), 305. 
about medical, social or psychological views instead of religious approach.

Among others, there found, at minimum, two directly related hadith on elderly in hajj. First is about the permission to perform hajj on behalf of an elderly who is not physically eligible to perform the hajj. The second contains some alternatives for those who have physical difficulties in hajj to still perform it by themselves, including elderly, such as to ride any 'vehicle' like camel as the traditional characteristic of Arabic peninsula at that time.

The first group of hadith implies that the elderly is permitted not to perform hajj due to physical condition and for his/her own good. However, the second group indicates that it is still strongly urged to perform hajj by themselves considering some special 'policies' and 'facilities' available. Therefore, what this paper aims to do is to find out the proper contextual and critical interpretation on this problem based on the hadith as the relevant source using the theory of mukhtalif ahadis. This is done through three questions to answer; First, how did hadith say about specific treatment of elderly hajj pilgrims? Second, how to deal with two groups of hadith which slightly look different? Third, how is the proper contextual interpretation of the hadith in Indonesian contemporary life?

\section{Research Method}

This is a qualitative research based on a mixed library and field data compilation technique. The primary library source consists of some main hadith compilation books, while the secondary contains books, journal articles, dissertation and website contents talking about the hajj specifically related to the elderly. The field data comes from interviews to three respondents which had played a roles as a member of hajj team, while one of which also served as the former chair of hajj division at the local branch of ministry of religious affair. The interviews were in semi structured one with the prepared questions arranged before.

Meanwhile, the analysis is based on the theory of mukhtalif ahadis which is a branch of matn (textual) critic clusters. It mainly focuses on the text or word of hadith. However, this does not mean that another component of hadith, sand or the transmission chain is fully ignored. When two difference hadith are found, for example, 
and one of them is known to have a very weak chain, then it would not be considered to apply the mukhtalif ahadis anymore. ${ }^{4}$ Therefore, a requirement to apply the theories and rules of this cluster is valid when both hadith have same strong and good chain of transmission. ${ }^{5}$ The status of hadith must be either sahih or hasan. ${ }^{6}$

Etymologically, mukhtalif means those which are different. It derives from ikhtalafa yakhtalifu and serves as isim fa'il or those who do any action. In its root, it means position at the back as the opposite of the position at the front. ${ }^{7}$ Meanwhile, hadith could mean saying of someone or the new thing as the opposite of the word 'old'. However, it is more popular as a term used to describe anything, including saying, action, agreement, psychological or physical character of Prophet Muhammad pbuh. ${ }^{8}$

In principle, as a cluster of ulum al hadith (sciences of hadith), mukhtalif ahadis aims to pay very much attention on each hadith right from the text to context to make sure there is no 'trashed' to throw away. Difference between hadith does not directly mean that one of them is accepted while another is rejected provided that both of them have the same quality of the chain transmission. Therefore, this cluster is worth very much to learn and practice as the differences among some Islamic sources, not only among hadiths, are unbearable because of the different context of each.

At general, the methods to deal with different hadith (es) are: First is al-jam'u wa al-tawfiq (to gather and to compromise). Second is tarjih (to prioritize one among another). Third is naskh (to eliminate one over another). Fourth is tawaqquf or tasaquth (not to consider both

4Automatically, when the condition occurs, the weaker one is not used right away. Arif Wahyudi mentioned that the different hadith should be maqbul or eligible as hujjah syar'i. Additionally, he said that differences must be between or among some hadith, not between hadith and the Qur'an or logical thinking. See, Arif Wahyudi, “Kontroversi Hadist-hadist Menangisi Mayit," Al-Ihkam, Vol. 9, No. 1 (June, 2014), 82.

5Other requirements, according to Arif Wahyudi, are as follow. First, the differences happen in the same context. Second, the difference is clear, such as when a hadith implies allowance while another shows prohibition. Third, the differences are in the same condition. See Arif Wahyudi, "Kontroversi Hadist-hadist..., 84.

'Edi Safri, "Al-Imam Al-Syafi'i; Metode Penyelesaian Hadist-Hadist Mukhtalif", dissertation unpublished, IAIN Jakarta, 1990, 129.

7Ibnu Mandzur, Lisan Al-Arab vol. IX (Beirut: Dar Shadr, s.a), 82.

8Imam Syafi' ie, Al-Risalah (Beirut: Dar al-Kutub al-Ilmiyyah, s.a), 342. 
of them). The arrangement of mentioning those four also shows hierarchical scale. Meaning to say, when it is still possible, the first method would be applied as it would accommodate two different hadith(es) so there would be no hadith over another. It makes the perfect compromise of the slightly different hadith.

Meanwhile, the second and the third method need some requirement as it would put one hadith over another so it could not be done randomly right away. Some requirement for the second method are as follow; the lack of the clear text (naskh sharih) relating to the problem, the impossibility to find the compromise point, and the good quality of both hadith either it is mutawatir or sahih. ${ }^{9}$ Shalahuddin Al-Adlabi added that in this method, there are some techniques to do including taqyid, takhsis, nasih mansukh, ta'wil, and asbab al wurud. 10 The same condition applies for the fourth method as it would not use both of hadith because of unbreakable differences. The requirement, therefore, is the lack of possibility to apply any method because of the real and big differences between.

\section{Hajj of Prophet Muhammad}

Hajj is one of ritual worships that does not originally come from Mohammad era for the first time.11 Long before his time, in the era of Abraham, ${ }^{12}$ hajj had been performed by those who believe in Allah (or

9Syaraf al-Qudhat, 'Ilmu Mukhtalif Ahadis: Ushuluhu wa Qawa'iduhu (Amman: AlJami'ah Al-Urduniyah, 2001), 60.

10Shalahuddin bin Ahmad al-Adlabi, Menalar Sabda Nabi; Menerapkan Metode Kritik Matan dalam Studi Hadist transl. Ita Qonita, (Yogyakarta: Bintang Pustaka Abadi, 2010), 325.

11Philip K. Hitti mentioned that at very first, hajj or pilgrimage is a rite of worship to the God of the Sun. Once, it was performed at the autumn and believed as a farewell ceremony to the God of the Sun as well as the welcoming party to the God of Rain. In the pre-Islamic era, he added that an annual celebration of North Arabia was performed together with the hajj rite heading to Ka'bah and Arafah in Zul Hijjah. Phillip K. Hitti, History of the Arabs transl. Cecep Lukman Yasin \& Dedi Slamet Riyadi, (Jakarta: Serambi, 2006), 168-169.

12In relation to hajj, Ali Syari'ati mentioned Abraham or Ibrahim as the oldest and the most rebellious man of history as he denied all idols on the earth, greatly loved and obeyed Allah, then (along with Ismail, his son) built the Ka'bah whose structure symbolizes Him in the world. Ali Shari'ati, Hajj; The Pilgrimage, (s.l: Free Islamic Literature, 1980), 31 and 44. 
hanif religion) ${ }^{13}$ although later, some changes inevitably happened. Historical notes from pre-Islamic Arab described that $K a^{\prime} b a h$, or the House of God, was full of idols which imply the deviation of faith in significant way. Apart from political side and other factors, this showed that the $K a^{\prime} b a h$ itself still played his old role as a worship house.

Therefore, though it needs verification, it makes sense if some sources noted that before and other than hajj wad' or farewell of hajj, Prophet Muhammad had ever performed the hajj. ${ }^{14}$ Considering the fact about deviation or the abuse of Ka'bah and the condition of Mecca before the hijrah, however, if that was true, it could be strongly predicted that the hajj was performed in a different way as what Prophet Muhammad and Moslems performed afterward. The command to perform hajj was later officially revealed to Prophet Muhammad when the condition allowed him to do so and there were no threat of Kafir Quraisy of Mecca anymore. ${ }^{15}$ Some said it was on fifth, sixth even ninth year of hijrah. ${ }^{16}$

Other than hajj, at seventh year of hijra, Prophet Muhammad had performed umra to the Mecca before the hajj wada'. It closely relates to the Testament of Hudaibiyah which allowed Moslems to perform the umra that year after the ban in the previous year. ${ }^{17}$ Meanwhile, the hajj wada' was on the tenth year of hijrah. This arose a question considering that Fath Makkah, a moment that signified victory of Islam at the Mecca, occurred two years before, the eighth of

13Peter Webb, “The Hajj before Muhammad: Journeys to Mecca in Muslim Narratives of Pre-Islamic History", in Venetia Porter and Liana Saif, The Hajj: Collected Essays, (Hockley: British Museum, 2013), 7-8.

${ }^{14}$ M. Quraish Shihab, Membaca Sirah Nabi Muhammad SAW dalam Sorotan Al-Qur'an dan Hadist-hadist Shahih, (Jakarta: Lentera Hati, 2012), 818. A note from Imam Ja'far Shadiq even mentioned that the hajj after hijrah of Prophet Muhammad was only once but before that, he often performed the hajj (about 20 times) and umrah (about three times) along with his companions. Muhammad Solikhin, Keajaiban Haji dan Umrah; Mengungkap Kedahsyatan Pesona Ka'bah dan Tanah Suci (Jakarta: Erlangga, 2013), 63.

15See for example, Al-Baqarah: 196 and Ali Imran: 97.

16M. Quraish Shihab, Membaca Sirah Nabawiyyah, 817-818.

17Khaled Abdelhay Elsayed and Kamaruzaman Yusoff, "The Implication of Peace Treaties in Disseminating Da'wah Islamiyah (the Islamic Call) among non-Muslims: A Special Reference to Hudaibiya Treaty", Australian Journal of Basic and Applied Science, Vol. 6 No. 7, (2012), 209. 
hijrah. It is mainly about why Prophet Muhammad postponed the agenda of hajj that long if the condition had allowed him to perform the hajj earlier.

Fath Makkah closely relates to the Hudaibiyah Treaty. History notes that in fact, the visit to Mecca was not well planned, since it was a kind of reaction from Moslem at Madina to the break of Hudaibiyah Treaty. To be short, the story began when the clan of Bakr which politically engaged to Meccan Quraish attacked the clan of Khuza'ah which was the companion of Madinan Moslems. This attack was based on the consideration that Madinan Moslem had been badly defeated in fighting the Roman army before ward so it was assumed there would have had been no power anymore. ${ }^{18}$

The attack to the Khuza'ah happened unbalanced as they were totally not prepared to offend the attack. This led them to run and finally reached the Mecca. According to the Hudaibiyah Treaty, there should not been any fight in haramayn, but this point was disobeyed and gave Rasulullah and Madinan Moslem no other option but to come to Mecca for a fight.

On the way to Mecca with about 10000 armies, Rasulullah got some additional key persons who declared faith and converted to Islam. They were Abbas bin Abdul Muthallib, Abu Sufyan bin Harist and Abdullah bin Abu Umayyah. Among them, Abu Sufyan as the political leader of Mecca had specific mission to do diplomacy in order Rasulullah and his armies not attack Mecca violently. This mission was successful as among the four groups of armies coming to the Mecca from different directions, there was only a group from the East which could not avoid the violent fight. Rasulullah could come to the Mecca peacefully with no blood. He visited the Ka'ba and did seven round tawaf which was later known as the tawaf of victory. Later, at the main door of Ka'ba, he addressed in front of Meccan Quraish and gave them full amnesty. He performed prayer together with Usamah and Bilal before walking around and destroying all the idols, paintings and pictures hang in all areas of The $K a^{\prime} b a .{ }^{19}$

${ }^{18}$ Akhmad Siddiq Thabrani, Di Tengah Pusaran Ka'bah; Sejarah, Keajaiban, Mitos dan Mistik (Depok: Keira Publishing, 2014), 120-122.

19Simeon Petroni, "Mecca, The Blessed Heart of Islam", in Silvio Ferrari and Andrea Benzo (ed), Between Cultural Diversity and Common Heritage: Legal and Religious Perspectives on the Sacred Places of the Mediterranean (London: Routledge, 2014), 322. 
Considering this, Rasulullah had actually got a chance to perform hajj right after the event because of the safe condition at specific and bilateral connection with Mecca at general, yet he 'waited' until the tenth year of hijra. It is strongly predicted that reason for Prophet Muhammad to perform the hajj that late covers; First, to accentuate the obligation for hajj once in a lifetime. Second, to imply a sign that the death of Prophet Muhammad was coming. Third, to indicate that the tenth year of hijrah is a good time after the series of battle following Fathu Makkah could be gone through.

Apart from historical dispute about how many times Prophet Muhammad performed the hajj during his life, notes about hajj recorded in both hadith (es) and prophetic history generally come from the event of hajj wada'. It becomes important not only because the event happened when the condition is really safe, but also because it signifies a farewell hajj implying that the due date of Prophet's last days was approaching.

\section{Hadith(es) on Hajj for Elderly}

Hadith on hajj are easily found in special chapters in some compilation hadith books. This chapter usually contains some subchapters which specifically classify the hadith based on more special themes. At general, most of the hadith on hajj describe the situation around the hajj wada' from the very first step until the end. Other than that, the hadith about hajj show the strong motivation to perform hajj. Hajj, for example, is said as one of five pillars of Islam, considered as honored as doing jihad (war for the sake of Allah), ${ }^{20}$ could erase the previous sinful deed and so on. ${ }^{21}$

Slightly, these hadith imply motivation for all Moslem to perform the hajj in any condition, although The Koran itself firmly notes that hajj is compulsory for those who can afford the way (man istatha'a ilaihi sabila).22 However, there found a few hadith which

\footnotetext{
${ }^{20}$ Ahmad Ibnu Ali Ibnu Hajar Al-Asqalani, Fathul Bari vol. 3 (Kairo: Al-Maktabah AlTawfiqiyyah, 2008), 492.

21See, for example, the first subchapter of kitab al hajj, which is bab wujub al hajj wa fadhlihi. Ahmad Ibnu Ali Ibnu Hajar Al-Asqalani, Fathul Bari vol. 3..., 488. See also Imam Bukhari, Shahih Bukhari vol. 1 (Istanbul: Darul Fikr, s.a ), 140.

${ }^{22}$ Ali Imron, 96-97. Furthermore, it is explained that Moslems are categorized into two in the sense of obligation to perform the hajj. First is those who are obliged, and
} 
mention special policy for certain persons not to perform the hajj by themselves when any condition occurs. This, for example, happens on those who have been elderly when the command to perform hajj had been revealed. As an alternative, a member of family or other person in charge would perform the hajj on behalf of them.

Some of them, in not totally same diction and wording, are narrated by Bukhari (number 1513, chapter hajj on the ride), Muslim (number 1334, chapter hajj for the weak) Ibnu Majah (number 2906, 2908, 2909, 5390, 5391, 5392), Abu Dawud (number 1809, chapter performing hajj on behalf of others), Tirmidzi (number 2909, chapter on hajj for elderly and the late men) and Nasa'i (2635, 2641, 2642).

The hadith reported a conversation between Prophet Muhammad and a woman in hajj wada' period. The woman asked Prophet Muhammad whether she could perform the hajj on behalf of her father who, in the time when the revelation of hajj came and the hajj wad' period, later, was disable to perform the hajj even when riding on the mount. Prophet Muhammad permitted her to do so.

The hadits is as follows 23

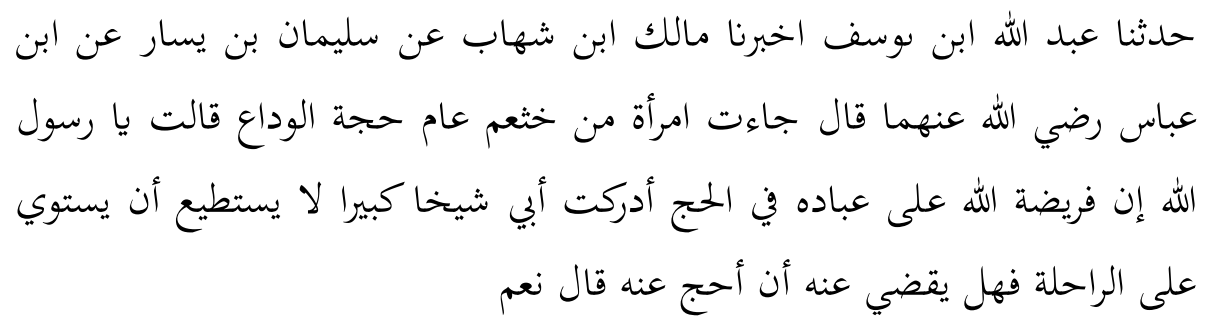

Another series of hadith with almost same diction and redaction is as follows 24

second is those who are not. The later refers to those who are not eligible because of either early ages or physical (or financial) ability. Ahmad Ibnu Ali Ibnu Hajar AlAsqalani, Fathul Bari..., 489. Relating to this, a hadith narrated by Tirmidzi mentioned that what makes hajj obliged for anyone is that when h/he has money (zaad) and vehicle (rahilah). Hadith number 813. Imam Tirmdzi, Al-Jami' Al-Sahih Sunan Tirmidzi vol. 3 (Lebanon: Dar Kutub Al-Ilmiyyah, 2011), 6.

${ }^{23}$ Hadith number 1513. Ahmad Ibnu Ali Ibnu Hajar Al-Asqalani, Fathul Bari..., 488. Compare to al-Bukhari, Shahih Bukhari vol. 1 (Istanbul: Darul Fikr, s.a ), 140.

${ }^{24}$ http:/ / library.islamweb.net/newlibrary / display_book.php?idfrom=3937\&idto=393 9\&bk_no=53\&ID=586 (Accessed on September 10, 2018). 


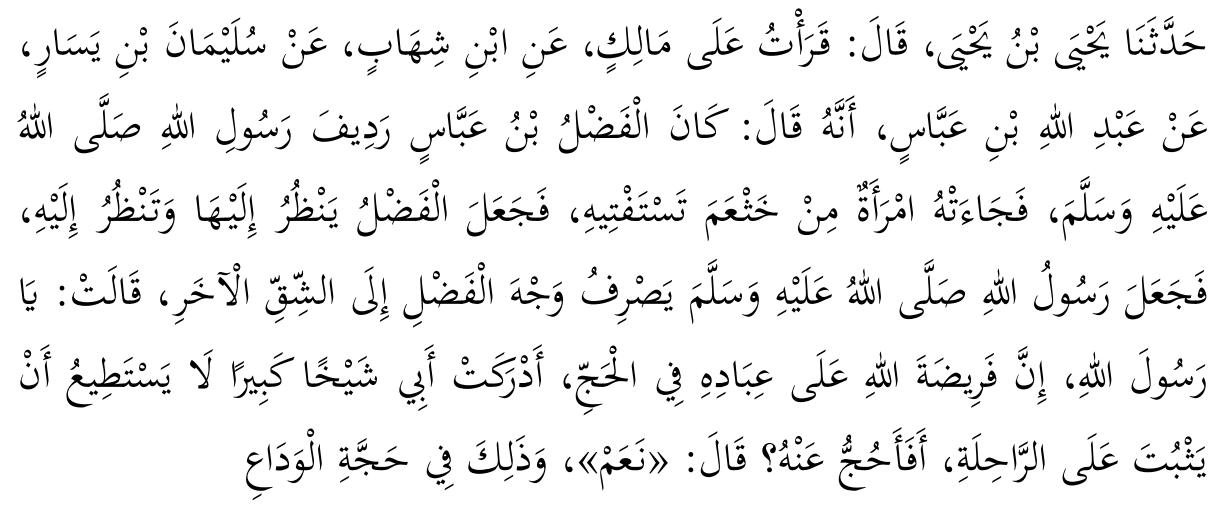

It is informed in one of syarh books (Tuhfat Al-Ahwadzi) that the father was actually a newly convert to Islam who was rich, so financially, he could afford to perform the hajj. However, his health problem did not allow him to even do a ride because he would not be stable on it. ${ }^{25}$ Meanwhile, Fathul Bari author mentioned that the main point of this hadith is not about the vehicle or instrument to perform the hajj, but physical and financial ability. Meaning to say, if anyone could not perform the hajj because the lack ability of either physical or financial, this policy applies. ${ }^{26}$

Another syarh book mentioned that this hadith indicates the permission to perform hajj for a woman on behalf of a man, moreover as a service of a daughter to the parents. Furthermore, she is allowed to perform the hajj without any mahrom if she believes she could be ok. It is also explained that the obligation for hajj still applies for those who can afford the cost materially but physically ill. ${ }^{27}$

Other versions of this hadith explained other related things, such as the same policy and rule for those who had been passed away yet need to pay the nazr to perform the hajj even umroh. The nazr was considered just like a debt and ahl waris (heir) of the man/woman is responsible to pay it, whether or not the late parents told and gave them wasiyyah (a message spoken before a man passes away).

${ }^{25} \mathrm{http}$ ://hadithportal.com/hadith-sharh-928-21662\&book=3 (Accessed on September 10, 2018).

${ }^{26}$ Ahmad Ibnu Ali Ibnu Hajar Al-Asqalani, Fathul Bari..., 489.

27 Yahya bin Syarif Abu Zakariyya An-Nawawi, Syarh Nawawi 'ala Muslim, (sl: Darul Khair, 1996), 97. 
However, some schools required the request from the elderly/or the late to perform the hajj on behalf of themselves, so this initiative could not come from the person in charge only. It is clearly described in the explanation (syarh) of hadith number 927 at Tirmidzi's hadith compilation. ${ }^{28}$

Those two cases indicate that doing hajj on behalf of other person is allowed in some specific condition. At general, it implies that elderly who could not bear to perform the hajj even by riding any supported vehicle is one of the privileged groups because anyone else could perform the hajj on behalf of him/her. Another part is the one who had died but had promised (nazr) to perform the hajj. His/her descent is even obliged to perform the hajj on behalf of him/her just like the obligation to pay back the debt he/she borrowed from anyone else.

However, other hadith imply the obligation for elderly or those with physical problems to still perform the hajj by using special policy that Prophet Muhammad mentioned. Some other hadith even suggest those who are not physically ill to facilitate the elderly or the sick by helping them in providing good facilities and chance in performing all series of hajj worship. Those policies refer, but not limited to, some of this condition:

First, Prophet Muhammad gave permission for Saudah to leave Muzdalifah first to avoid the crowd due to her physical condition. ${ }^{29}$ The almost same condition happened to Asma binti Abu Bakar (when she stayed in Muzdalifah) who did the same, particularly leaving just after the dawn to Mina. To her slave, she explained that her action had been permitted by Prophet Muhammad.30 In another moment, Rasulullah ordered Ummu Salamah to do tawaf behind other hajj

28Imam Tirmdzi, Al-Jami' Al-Sahih Sunan Tirmidzi..., 74-75.

${ }^{29} \mathrm{~A}$ hadith narrated by Aisyah shows that in Muzdalifah, one of Prophet Muhammad wives, Saudah, permitted to leava to Mina first considering her phyisical condition (fat and heavy to carry her body). She planned that by doing so, she would be able to perform the jumrah rites not in any big crowd. Hadith number 812, chapter hajj, subchapter sunnah to prioritize the weak and women before the crowd. Fu'ad Abdul Baqi, Mutiara Hadits Shahih Bukhari-Muslim Al-Lu'lu' wal Marjan transl. Salim Bahreisy, (Surabaya: Bina Ilmu, 2005),. 418-419.

${ }^{30}$ Hadith number 813, Fu'ad Abdul Baqi, Mutiara Hadits Shahih..., 419. 
pilgrims while riding due to her sickness. ${ }^{31}$ Not only women, Prophet Muhammad also gave special policy to Ibnu Abbas and some member of his (prophet's) family to leave first to Mina at the Muzdalifah night. 32

Second, Prophet Muhammad once did a ride in hajj 33 then stood on it. ${ }^{34}$ Particularly in the tawaf rite, on his camel, he gave a mark on his hand then say takbir everytime he performed the rukn.35 Additionally, he also rode in throwing jumrah although in another moment, he did it by walking. ${ }^{36}$ It is also reported that he once put his belonging, including the food, on the camel he rode. ${ }^{37}$

However, those do not mean that riding automatically becomes obligation or requirement for those who perform the hajj. In fact, walking on foot is preferable for those who are able to do so, while riding is the second alternative. It is worth to take a note that there still found a dispute on the preferability between riding and walking on foot. ${ }^{38}$ Performing hajj on the ride was also narrated in other places and persons. One of them was about Prophet's comment to Aisyah bint Abu Bakar who said that she did not perform umrah yet when others had made it. Rasulullah then ordered Abdurrahman, her brother, to accompany her and leave for Umrah from Tan'im. At that

31Hadit number 1633. Ahmad Ibnu Ali Ibnu Hajar Al-Asqalani, Fathul Bari..., 630. Doing tawaf beyond other pilgrims while riding is for the safety of the rider.

${ }^{32}$ Hadith number 814, Fu'ad Abdul Baqi, Mutiara Hadits Shahih..., 419.

33Hadith number 1517, Ahmad Ibnu Ali Ibnu Hajar Al-Asqalani, Fathul Bari..., 491. This was intended to see other pilgrims and welcome them if they have something to ask to him, according to a hadith narrated by Muslim from Jabir. Ahmad Ibnu Ali Ibnu Hajar Al-Asqalani, Fathul Bari..., 631. The same hadith was found at Sunan Tirmidzi, hadith number 865. Imam Tirmdzi, Al-Jami' Al-Sahih Sunan Tirmidzi..., 38. ${ }^{34}$ Imam Bukhari, Shahih Bukhari vol. 1., 141.

${ }^{35}$ Hadith number 1633, Ahmad Ibnu Ali Ibnu Hajar Al-Asqalani, Fathul Bari..., 630. 36Hadith number 895-896. Imam Tirmdzi, Al-Jami' Al-Sahih Sunan Tirmidzi..., 51.

${ }^{37}$ Ahmad Ibnu Ali Ibnu Hajar Al-Asqalani, Fathul Bari..., 492. This became role model for those who performed hajj before Utsman ibnu Affan, for the very first time, did not put any belonging on his ride.

${ }^{38}$ Ahmad Ibnu Ali Ibnu Hajar Al-Asqalani, Fathul Bari..., 490-491. Another thing to consider in riding a camel is about the dirt or faces of camel. Therefore, some Islamic scholars prohibit riding in a hajj without any reasonable cause or so called $u z r$. Ahmad Ibnu Ali Ibnu Hajar Al-Asqalani, Fathul Bari..., 631. Compare to the explanation of Tirmidzi which quoted Asy-Syafi' ie's opinion in it. 38 . 
time, Aisyah rode the camel then performed the umra. 39

The permission of Prophet Muhammad to perfom hajj in different policies was also claimed by Ibnu Umar who was used to prioritize the weak from his family in performing hajj, particularly when they were going to reach Mina. Usually, the family would be located in Masy'aril Haram at the night to do dhikr so they could arrive at Mina early at the dawn to do jumrah. Ibnu Umar confirmed that his action was under the permission of Rasulullah. ${ }^{40}$

In short, the second group consists of hadith which imply that in any hard condition, it is still recommended to perform the hajj by selves. Certainly, this applies by utilizing some 'facilities' and using strategies, such as riding on any compatible vehicle, avoiding the big crowd, setting the schedule and so on and so forth. Motivation to perform hajj, to sum up, according to the second group of hadith, is still accentuated.

Considering the theories of mukhtalif ahâdits, hadith about elderly pilgrims could be compromised using the first method, which is al jam' $u$ wa al-tawfiq (to gather and to compromise). It relates to the good quality of the hadith which could be seen from the compilation book on which they come from. Furthermore, the difference between or among two is the slight difference instead of the contradiction. To sum, at last, the first hadith are more about pilgrims with really serious health problem, either because of age or any disease. Meanwhile, the second hadith describe non-emergency condition in which pilgrims can still stand to do all series of hajj worship using some facilities and helping tools such as wheelchair, the help of the guide or by relying on some health facilities and other special policies for elderly.

This first method makes it possible to take two hadith all the way around without putting a side one of both. The first hadith apply in certain condition, while another applies in other condition. To avoid any double standard consideration in determining whether a next pilgrim's condition could be categorized into the first or the two, it would be adequate to pay attention to the health policy and through

\footnotetext{
${ }^{39}$ Hadith number 1516 and 1518. Ahmad Ibnu Ali Ibnu Hajar Al-Asqalani, Fathul Bari..., 491. Compare to Imam Bukhari, Shahih Bukhari vol. 1..., 140-141.

40Hadith number 816. Fu'ad Abdul Baqi, Mutiara Hadits Shahih, 420.
} 
diagnostic result of medical team, as applied in Indonesian hajj system.

\section{Hajj of Elderly in Indonesia}

In Indonesia, the management of hajj belongs to authority of the Ministry of Religious Affair by its special division called Direktorat Jenderal Penyelenggaraan Haji and Umrah or General Directorate for Hajj and Umrah. It operates through some branches in every district which directly serves the next pilgrims since the step of registration process to the departure even arrival time. At the time of registration, the next pilgrims are required to pay a desk posted cost about 25 million IDR. Later, they would pay the rest of the cost in the close time before the departure. Additionally, they also need to show the identification cards along with doctor certificate from local hospital at the registration time. ${ }^{41}$

Mr. Afandi, the former chair of hajj division of Indonesian Ministry of Religious Affair of Pamekasan Branch, mentioned that next pilgrims are supposed to wait about 23 years after the registration time for the departure. However, he added, the waiting period does not apply to all next pilgrims because there found a special policy for elderly so they do not need to wait that long. Three or four years after the registration, the district branch could recommend a number of elderly to depart for hajj. Elderly category is based on the age, i.e. 75 years at minimum, instead of health condition. 42 It was also informed that elderly up to 83 years deserve for the rest of national quota. ${ }^{43}$ This implies that a healthy elderly would be more prioritized to depart first to perform the hajj rather than the sick younger next pilgrims. Moreover, there was no maximum age limit for the next pilgrims. It is even found a minimum

41Interview with Mr. Afandi,... in his office, Jl. Brawijaya, Pamekasan, on August 27, 2018, 15.00-16.00.

42Interview with Mr. Abd. Halik Yadi, an experienced guide who served as an officer of TPHI (Tim Pemandu Haji Indonesia, Indonesian Hajj Guide Team) at 1998 and 2006 and the chief of pilgrim group or as know as ketua rombongan at 2016. The interview in his office at IAIN Madura, August 05, 2018. in his office at IAIN Madura, August 05, 2018.

43Mario Effendi, “Usia 83 Tahun ke Atas Berhak Mendapat Sisa Kuota Nasional," in https:// haji.kemenag.go.id/v3/content/usia-83-tahun-ke-atas-berhak-mendapatsisa-kuota-nasional (Accessed on August 18, 2018). 
age for hajj, which is 12 years. 44

When the recommendation gets approval from the central hajj committee, the elderly could depart and perform the hajj right away in the closest hajj session. This policy makes much sense on why in almost every pilgrimage season, elderly dominated the whole pilgrims in number. ${ }^{45}$ The same policy even also applies for the one who accompany the elderly, such as children and other family members. This applies although in the formal regulation, there is no need for elderly-as well as women-to have a company in performing the hajj. ${ }^{46}$

However, they would not be permitted to leave or are supposed to delay the departure one year ahead when the health check-up process diagnosed something serious. It is commonly known that the aging closely relates to various types of disease, so the check-up process is also performed more intensive for elderly other than regular pilgrims. ${ }^{47}$ The same condition applies for pregnant women as the permission to perform the hajj only applies before 14 weeks or after 26 weeks pregnancy. In addition to elderly or pregnant women, in the close time before departure, all the next pilgrims are required to show a letter called isthitha'ah (means good health condition letter) as one of requirements before paying the rest cost of hajj. ${ }^{48}$ If there found any serious disease or health problem, it would be considered to postpone the departure one year ahad.

However, Mr. Abd. Halik Yadi, an experienced guide who served as an officer of TPHI (Tim Pemandu Haji Indonesia,

${ }^{44}$ Interview with Mr. Afandi,... in his office, Jl. Brawijaya, Pamekasan, on August 27, 2018, 15.00-16.00.

${ }^{45}$ There found even a rumor at the last 2013, it would be considered to manage a special group flight for elderly. Redaksi, "Pemerintah Pertimbangkan Rancangan Kloter Khusus Lansia", https://haji.kemenag.go.id/v3/node/1082 (Accessed on August 18, 2018).

46Interview with Mr. Afandi,... in his office, Jl. Brawijaya, Pamekasan, on August 27, 2018, 15.00-16.00.

${ }^{47}$ One of common diseases of hajj pilgirms is diabetes as the prevalence of diabetes increases with age. See. Mahmoud Ibrahim (et all), "Recommendations for Management of Diabetes and Its Complications during Hajj (Muslim Pilgrimage)", Clinical Medicine, Vol. 11, No. 3 (June, 2011).

48Interview with Mr. Afandi,... in his office, Jl. Brawijaya, Pamekasan, on August 27, 2018, 15.00-16.00. 
Indonesian Hajj Guide Team) at 1998 and 2006 and the chief of pilgrim group or as known as ketua rombongan at 2016, mentioned that if the disease or health problem could still be managed at the close time, then it would be well cared and observed whether the next pilgrim could depart that year. 49

Before leaving for hajj, next pilgrims would also experience two times of hajj manasik (procedural education on doing hajj). The first is held by sub district office of The Ministry of Religious Affair and the second is by the district office. Some private KBIH (Kelompok Bimbingan Ibadah Haji; Hajj Guide Team), which is not popular anymore today, often hold the manasik hajj additional program. ${ }^{50}$ One of the important materials in the manasik is about facilities and policies for elderly pilgrims which, unfortunately, is typically not well mastered by elderly pilgrims so they tend to the miss the things they deserve for. ${ }^{51}$ In fact, Indonesian hajj committee had prepared many facilities and supporting systems to make sure that the health of pilgrims, particularly elderly or those with serious health problems could be well maintained during the hajj. This does not only relate to the previous disease history, but also the hot weather, tiring schedule of hajj performance as well as the big crowd at some main points of hajj rite spots. The special treatment ranges from facilities from hometown to the destination.

At general, there found hajj teams which consist of karu (ketua regu, chair of group, leading 10 pilgrims) and karom (ketua rombongan, chair of flight group, leading for groups). This is actually more than adequate to ensure all the process run well. In addition to it, every flight group (consisting of about 400 pilgrims) is equipped by a health team called TKHI (Tim Kesehatan Haji Indonesia or Health Service Team of Indonesian Hajj) consisting of 3 persons. One of them is a

${ }^{49}$ Interview with Mr. Abd. Halik Yadi,... in his office at IAIN Madura, August 05, 2018.

50Interview with Mr. Afandi,... in his office, Jl. Brawijaya, Pamekasan, on August 27, 2018, 15.00-16.00.

51The idea to set special class for elderly in hajj manasik had become an issue, yet it had not given much influence yet at national level. Redaksi, "Kemenag Yogyakarta Siap Buka Kelas Bimbel Manasik Berbasis Lansia dan Disabilitas", in https:/ / haji.kemenag.go.id/v3/content/kemenag-yogyakarta-siap-buka-kelasbimbel-manasik-berbasis-lansia-dan-disabilitas Accessed on August 18, 2018. 
doctor and the two are paramedics.52 The main jobs of TKHI are; checking up the health condition of hajj pilgrims, maintaining the health condition, serving any health complaints, observing the disease suffered and creating a healthy environment for the pilgrims. ${ }^{53}$

Meanwhile, specifically, some facilities for elderly pilgrims are as follow. First, the existence of BKHI which stands for Balai Kesehatan Haji Indonesia (Indonesian Health Center of Hajj). It is such a local hospital for Indonesian pilgrims who deal with health problem. This hospital is under the management of KKHI, Kantor Kesehatan Haji Indonesia (Health Office of Indonesian Hajj) and located in three cities; Jeddah, Mecca and Madina. Serving as the first destination for Indonesian patients, this hospital would send patients with serious health problem that it can't handle and manage with to Arab Saudi hospital. 54

Second, the role of non-flight group team. This team works during 70 work days to deal with various problems, specifically what can't be handled by flight group team. The example is the sicks who are not recovered until the return date of hajj pilgrims. Therefore, this team is known as the fullest work team as they depart at the earliest period and return home at the latest period. ${ }^{55}$ This team works at three airports in Jeddah, Mecca and Madina. They were qualified in speaking 'ammiyah Arabic to give maximum help for the pilgrims. Relating to the treatment of elderly or the sicks, they serve to record the data and take them to Indonesian hospital of PKHI at the airports. Sometimes, the members of this team like to push the wheelchair of the pilgrims. ${ }^{56}$

Third, some units of wheelchair are available for elderly pilgrims on their way to the plane, the hotel and during the hajj process until they come back home. Pilgrims could bring it by themselves or use

52Interview with Mr. Abd. Halik Yadi,... in his office at IAIN Madura, August 05, 2018.

53See, "Pertanyaan yang Paling Sering Ditanyakan," in https://haji.kemenag.go.id/v3/ragam/faq-haji?body_value=\&page=1 Accessed on August 18, 2018.

${ }^{54}$ Interview with Mr. Afandi,... in his office, Jl. Brawijaya, Pamekasan, on August 27, 2018, 15.00-16.00.

55Interview with Mr. Halik Yadi and Mr. Afandi.

56Interview with Ayis Mukholik, a member of non-flight team of Indonesian hajj 2018 via WhatsApp messenger, May 29, 2019. 
public facility provided by Indonesian hajj committee and hotel they stay in. ${ }^{57}$ Recently, in hajj season 2018, P3JH, Pertolongan Pertama pada Jemaah Haji or First Aid Team of Hajj Pilgrims, provide some units of wheelchair and stretcher in the area of Mina. ${ }^{58}$ Additionally, each airport provides wheelchair facilities, yet some pilgrims prefer to buy the wheelchair at either Mecca or Madina because they need wheelchair right after staying at the both cities although before at the departure time, they did not. 59

Fourth, a policy of TPIHI (Tim Pemandu Ibadah Haji Indonesia, Indoensian Hajj Guiding Team) for elderly or those with high risk problem not to perform all un-cumpolsary series of worships, such as in Muzdalifah and Mina. In wuquf series, those who can't bear to do regular wuquf at Arafah would perform so called wuquf safar in an ambulance-look vehicles. ${ }^{60}$

Fifth, facilities to perform $s a^{\prime} i$ and thawaf. It comes in special lanes to perform both two so that the elderly pilgrims or those with physical limitation would not be trapped in a very big crowd like regular pilgrims. This policy and facility belong to Arab Saudi hajj committee. They provide special lanes for both $s a^{\prime} i$ and tawaf which are mainly set and designed for elderly with wheelchair or those who want to avoid the big unbearable crowd of people. ${ }^{61}$

However, Mr. Halik mentioned that for thawaf, pilgrims usually do not prefer this lane-located at the upper floor-because it takes much more time to go through the lane. They also do not find any chance to approach the black stone (hajar aswad). In fact, this threefloors lane is made to ensure certain pilgrims, elderly, among others, could do tawaf enjoyfully and safely, although it is open for all types

\footnotetext{
57Interview with Mr. Afandi,... in his office, Jl. Brawijaya, Pamekasan, on August 27, 2018, 15.00-16.00.

${ }^{58}$ Muhammad Subarkah, "Layanan Kursi Roda bagi Jama'ah Haji Disiapkan", in https://www.republika.co.id/berita/jurnal-haji/berita-jurnalhaji/18/06/08/pa0jm5385-layanan-kursi-roda-bagi-jamaah-haji-disiapkan)/ 59Interview with Ayis Mukholik,... via WhatsApp messenger, May 29, 2019.

${ }^{60}$ Interview with Mr. Abd. Halik Yadi,... in his office at IAIN Madura, August 05, 2018.

${ }^{61}$ Interview with Mr. Abd. Halik Yadi,... in his office at IAIN Madura, August 05, 2018.
} 
of pilgrims.62 As an alternative, those with wheelchair have exclusive schedule to perform tawaf in the evening starting from 21.00 till 03.00.63 Different from the tawaf lane which is open for any pilgrim, lane for $s a^{\prime} i$ is only for elderly or those with wheelchair and serious health problem. The guide-either family member or person in charge - is also permitted to enter the lane along with the pilgrims. ${ }^{64}$

Sixth, the facility of local vehicles operating between Masjidil Haram and hotel as the alternative of Salawat Bus which only operates in the range of 2000 meters. The bus operates 24 hours and could reach hotel in sector 7 and 8 at the location of Jarwal which is out of Salawat Bus route and becomes the first vehicle to ride before the Salawat Bus. ${ }^{65}$

Seventh, the use of special accessories (bracelet) designed for elderly or those with high risk health condition. There are mainly two types of bracelet. The first is bracelet for every pilgrim and the second is for those with high risk health condition and elderly. ${ }^{66}$ There was once a trial of GPS bracelet use for elderly in the last 2016, yet it did not work continuously due to the big cost. ${ }^{67}$

Eighth, the room arrangement at the hotel. At the hotel or popularly known as maktab, the elderly are usually set to stay at the first floor, or at maximum at the seventh floor so the health team could be nearby. ${ }^{68}$ This will make them easier to go upstairs or downstairs although facilities like lift are usually available. The

62 Interview with Mr. Abd. Halik Yadi,... in his office at IAIN Madura, August 05, 2018.

63In the last 2013, it was informed that Arab Saudi government set the evening schedule for those with wheelchair to do tawaf. Redaksi, "Tawaf Jamaah Pakai Kursi Roda Dijadwalkan Malam Hari," in https://haji.kemenag.go.id/v3/node/1399. Accessed on August 18, 2018.

64Interview with Mr. Halik Yadi,... in his office at IAIN Madura, August 05, 2018.

65Redaksi, "PPIH Siapkan Transportasi Khusus Jemaah Haji", in https:/ / haji.kemenag.go.id/v3/content/ppih-siapkan-transportasi-khusus-jemaahhaji-lansia. Accessed on August 18, 2018.

66Interview with Mr. Afandi,... in his office, Jl. Brawijaya, Pamekasan, on August 27, 2018, 15.00-16.00.

67Diaz, "Musim Haji 2016 Kemenag akan Uji Cob Gelang GPS", https:/ / haji.kemenag.go.id/v3/content/musim-haji-2016-kemenag-akan-uji-cobagelang-gps (Accessed on August 18, 2018).

68Interview with Mr. Abd. Halik Yadi,... in his office at IAIN Madura, August 05, 2018. 
almost same arrangement also applies in a flight group (popular as kloter, stands for kelompok terbang, a flight group) which was set in consideration of some factors and one of which is the age of pilgrims. Other considering factors are cultural background, education level, religious knowledge and the health condition. ${ }^{69}$

Eighth, the medicine available for pilgrims. The standard medicine is provided, yet it could not cover any specific medicine for certain diseases. Therefore, the pilgrims themselves need to provide it by themselves. ${ }^{70}$

Ninth, the obligation for every next pilgrims to have meningococcal vaccine before the departure as recommended by Saudi Arabian government. Furthermore, the pneumococcal vaccine is currently recommended for Indonesian pilgrims older than 65 years old. ${ }^{71}$

Additionally, some non-government organization also offer service for so called badl hajj, which literally means a service for those who can't physically perform the hajj, either elderly or those with serious health problem. ${ }^{72}$ The customer of badl hajj would pay for someone who performs all the process of hajj on behalf of him/her by mentioning his/her name in the niyyah of hajj. This is usually done by so called muqimin, Indonesians who temporarily live in Mecca and surrounding for work or study and make the badl hajj as secondary occupation.

\section{Conclusion}

Hadith(es) on hajj of elderly are generally split into two categories. The former implies suggestion to delegate the hajj to someone else, while the latter urges them to still perform the hajj by themselves. These slighty-look-different hadith(es) find the

${ }^{69}$ M. Julius St, Manajemen Perjalanan Haji Reguler, (Malang: UB Press, 2011), 8.

70 Interview with Mr. Afandi,... in his office, Jl. Brawijaya, Pamekasan, on August 27, 2018, 15.00-16.00.

71See Harunor Rashid (et al), "The Potential for Pneumococcal Vaccination in Hajj Pilgrims: Expert Opinion" Travel Medicine and Infectious Disease, Vol. 11, No. 5, (2013), 291.

${ }^{72}$ Among others, badl hajj is clearly explained in Said Agil Husin Al Munawar and Abdul Halim, Fikih Haji; Menuntun Jama'ah Mencapai Haji Mabrur, (Jakarta: Ciputat Press, 2003), 194-212. 
compromise point using the method of al jam'u wa al-tawfiq (to gather and to compromise) considering of both contexts. The suggestion applies for those with very serious health problem, while the command is for those who still can cope with the health condition while using supportive facilities and policies.

In Indonesia with the majority of hajj pilgrims comes from elderly, special hajj manasik for this group is worth to consider to ensure some existing related policies well understood and properly used. Both policies and facilities are fairly adequate, though some improvement and evaluation are still needed. However, without the segmented hajj manasik held in a small class and intensive learning condition, it would be hard to maintain healthy and independent elderly pilgrims with the good knowledge or information mastery.

\section{Bibliography}

\section{Books, Journals and Dissertation}

A. Alzeer (et al), "Tuberculosis is the Commonest Cause of Pneumonia Requiring Hospitalization During Hajj (Pilgrim to Makkh)," Journal of Infection, Vol. 36, issue 3 (May 1998).

Al Munawar, Said Agil Husin and Abdul Halim. Fikih Haji; Menuntun Jama'ah Mencapai Haji Mabrur. Jakarta: Ciputat Press, 2003.

Al-Adlabi, Shalahuddin bin Ahmad. Menalar Sabda Nabi; Menerapkan Metode Kritik Matan dalam Studi Hadist transl. Ita Qonita. Yogyakarta: Bintang Pustaka Abadi. 2010.

Al-Asqalani, Ahmad Ibnu Ali Ibnu Hajar. Fathul Bari vol. 3. Kairo: AlMaktabah Al-Tawfiqiyyah, 2008.

Al-Qudhat, Syaraf. 'Ilmu Mukhtalif Ahadis: Ushuluhu wa Qawa'iduhu. Amman: Al-Jami'ah Al-Urduniyah, 2001.

Alzeer, Abdulaziz H. "Respiratory Tract Infection during Hajj", Annals of Thoracic Medicine, Vol. 4 (2) (Apr-Jun 2009).

An-Nawawi, Yahya bin Syarif Abu Zakariyya. Syarh Nawawi 'ala Muslim. sl: Darul Khair, 1996.

Baqi, Muhammad Fu'ad Abdul. Mutiara Hadits Shahih Bukhari-Muslim Al-Lu'lu' wal Marjan transl. Salim Bahreisy. Surabaya: Bina Ilmu, 2005.

Bukhari, Imam. Shahih Bukhari vol. 1. Istanbul: Darul Fikr, s.a.

Elsayed, Khaled Abdelhay and Kamaruzaman Yusoff, "The Implication of Peace Treaties in Disseminating Da'wah 
Islamiyah (the Islamic Call) among non-Muslims: A Special Reference to Hudaibiya Treaty", Australian Journal of Basic and Applied Science, Vol. 6 (7), (2012).

Ferrari, Silvio and Andrea Benzo (ed), Between Cultural Diversity and Common Heritage: Legal and Religious Perspectives on the Sacred Places of the Mediterranean. London: Routledge, 2014.

Hitti, Phillip K. History of the Arabs. transl. Cecep Lukman Yasin \& Dedi Slamet Riyadi. Jakarta: Serambi, 2006.

Ibrahim, Mahmoud (et al), "Recommendations for Management of Diabetes and Its Complications during Hajj (Muslim Pilgrimage)", Clinical Medicine, Vol. 11 (3) (June, 2011).

M. Julius St. Manajemen Perjalanan Haji Reguler. Malang: UB Press. 2011.

Mandourah, Yasser (et al), "Clinical and Temporal Patterns of Severe Pneumonia Causing Critical Illness during Hajj", BMC Infectious Disease, Vol. 12 (117), (2012).

Mandzur, Ibnu. Lisan Al-Arab. Beirut: Dar Shadr, s.a.

Porter, Venetia and Liana Saif. The Hajj: Collected Essays. Hockley: British Museum, 2013.

Rashid, Harunor (et al), "The Potential for Pneumococcal Vaccination in Hajj Pilgrims: Expert Opinion" Travel Medicine and Infectious Disease, vol. 11 (5) (June 2013).

Safri, Edi. "Al-Imam Al-Syafi'i; Metode Penyelesaian Hadist-Hadist Mukhtalif", dissertation, IAIN Jakarta, 1990.

Shari'ati, Ali. Hajj; The Pilgrimage. s.l: Free Islamic Literature, 1980.

Shihab, M. Quraish. Membaca Sirah Nabi Muhammad SAW dalam Sorotan Al-Qur'an dan Hadist-hadist Shahih. Jakarta: Lentera Hati, 2012.

Solikhin, Muhammad. Keajaiban Haji dan Umrah; Mengungkap Kedahsyatan Pesona Ka'bah dan Tanah Suci. Jakarta: Erlangga, 2013.

Syafi'ie, Imam. Al-Risalah. Beirut: Dar al-Kutub al-Ilmiyyah. s.a

Tariq A. Madani (et al), "Causes of Hospitalization of Pilgrims during the Hajj Period of the Islamic Year 1423 (2003)," in Ann Saudi Med, Vol. 26(5), (September-October 2006).

Thabrani, Akhmad Siddiq. Di Tengah Pusaran Ka'bah; Sejarah, Keajaiban, Mitos dan Mistik. Depok: Keira Publishing, 2014. 
Tirmdzi, Imam. Al-Jami' Al-Sahih Sunan Tirmidzi vol. 3. Lebanon: Dar Kutub Al-Ilmiyyah. 2011.

Wahyudi, Arif. "Kontroversi Hadist-hadist Menangisi Mayit," AlIhkam, vol 9, numb. 1 (June, 2014).

\section{Internet Websites}

Diaz, "Musim Haji 2016 Kemenag akan Uji Cob Gelang GPS", https://haji.kemenag.go.id/v3/content/musim-haji-2016kemenag-akan-uji-coba-gelang-gps (Accessed on August 18, 2018).

http://hadithportal.com/hadith-sharh-928-21662\&book=3

http://library.islamweb.net/newlibrary/display_book.php?idfrom=3 937\&idto $=3939 \& b k \_$no $=53 \&$ ID $=586$

Redaksi, "60 Jama'ah Haji Indonesia 2018 Didominasi Lansia”, in "https://haji.okezone.com/read/2018/04/25/398/1891271/60jamaah-haji-indonesia-2018-didominasi-lansia.

Redaksi, "Kemenag Yogyakarta Siap Buka Kelas Bimbel Manasik Berbasis Lansia dan Disabilitas", in https:/ / haji.kemenag.go.id/v3/content/kemenag-yogyakartasiap-buka-kelas-bimbel-manasik-berbasis-lansia-dan-disabilitas

Redaksi, "Pemerintah Pertimbangkan Rancangan Kloter Khusus Lansia", https://haji.kemenag.go.id/v3/node/1082

Redaksi, "Pertanyaan yang Paling Sering Ditanyakan," in https:// haji.kemenag.go.id/v3/ragam/faqhaji?body_value $=$ \&page $=1$

Redaksi, "PPIH Siapkan Transportasi Khusus Jemaah Haji", in https://haji.kemenag.go.id/v3/content/ppih-siapkantransportasi-khusus-jemaah-haji-lansia.

Redaksi, "Tawaf Jamaah Pakai Kursi Roda Dijadwalkan Malam Hari," in https://haji.kemenag.go.id/v3/node/1399.

Subarkah, Muhammad. "Layanan Kursi Roda bagi Jama'ah Haji Disiapkan", in https://www.republika.co.id/berita/jurnalhaji/berita-jurnal-haji/18/06/08/pa0jm5385-layanan-kursi-rodabagi-jamaah-haji-disiapkan

\section{Interview}

Interview with Mr. Halik Yadi, an experienced guide who served as an officer of TPHI (Tim Pemandu Haji Indonesia, Indonesian Hajj 
Guide Team) at 1998 and 2006 and the chief of pilgrim group or as know as ketua rombongan at 2016. The interview in his office at IAIN Madura, August 05, 2018.

Interview with Mr. Afandi, the former chair division of hajj, The Ministry of Religious Affair, Pamekasan district, in his office, Jl. Brawijaya, Pamekasan, on August 27, 2018, 15.00-16.00.

Interview with Ayis Mukholik, a member of non-flight team of Indonesian hajj 2018 via WhatsApp messenger, May 29, 2019. 